University of Nebraska - Lincoln

DigitalCommons@University of Nebraska - Lincoln

\title{
Susceptibility of commercial oat cultivars to Cryptolestes pusillus and Oryzaephilus surinamensis
}

James E. Throne

USDA-ARS, Manhattan, KS, james.throne@ars.usda.gov

Douglas C. Doehlert

USDA-ARS

Michael S. McMullen

North Dakota State University

Follow this and additional works at: https://digitalcommons.unl.edu/usdaarsfacpub

Throne, James E.; Doehlert, Douglas C.; and McMullen, Michael S., "Susceptibility of commercial oat cultivars to Cryptolestes pusillus and Oryzaephilus surinamensis" (2003). Publications from USDA-ARS / UNL Faculty. 2061.

https://digitalcommons.unl.edu/usdaarsfacpub/2061

This Article is brought to you for free and open access by the U.S. Department of Agriculture: Agricultural Research Service, Lincoln, Nebraska at DigitalCommons@University of Nebraska - Lincoln. It has been accepted for inclusion in Publications from USDA-ARS / UNL Faculty by an authorized administrator of DigitalCommons@University of Nebraska - Lincoln. 


\title{
Susceptibility of commercial oat cultivars to Cryptolestes pusillus and Oryzaephilus surinamensis
}

\author{
James E. Throne ${ }^{\mathrm{a}, *}$, Douglas C. Doehlert ${ }^{\mathrm{b}}$, Michael S. McMullen ${ }^{\mathrm{c}}$ \\ ${ }^{a}$ US Department of Agriculture, Agricultural Research Service, Grain Marketing and Production Research Center, \\ 1515 College Avenue, Manhattan, KS 66502, USA \\ ${ }^{\mathrm{b}}$ US Department of Agriculture, Agricultural Research Service, Wheat Quality Laboratory, Harris Hall, \\ North Dakota State University, Fargo, ND 58105, USA \\ ${ }^{\mathrm{c}}$ Department of Plant Sciences, North Dakota State University, Loftsgard Hall, Fargo, ND 58105-5051, USA
}

Accepted 19 November 2001

\begin{abstract}
Susceptibility to two storage insect pests [(Cryptolestes pusillus (Schönherr) and Oryzaephilus surinamensis (L.)] of eight commercial oat cultivars from the United States was determined in laboratory studies. Duration of insect development was shorter and number of progeny produced was greater on cracked than on whole oats. Simulations based on data from the study showed that insect populations would reach the threshold level for treatment in 2-3 months of storage at $30^{\circ} \mathrm{C}$ on cracked oats. Insect population development was slowest on the hulless cultivar Paul when the oat kernels were cracked. Simulations also indicated that all cultivars of whole oats tested could be stored for at least $1 \mathrm{yr}$ at $30^{\circ} \mathrm{C}$ without reaching the threshold for treatment when infested with these two species of insects, and insect populations would decrease over time on the cultivars Don, Jerry, Milton, NewDak, Otana, and Valley. Analyses of oat grain quality characteristics, including kernel weight, groat hardness, and groat composition, provided little insight into the mechanism of observed differences in insect development among cultivars. Hardness of the kernels (as indicated by \% broken groats after dehulling) may be related to near immunity to these two species of insects in whole Otana. Steaming whole oats to inactivate hydrolytic enzymes in the trichomes of the pericarp did not increase susceptibility to these two species of insects, suggesting that enzymes in the trichomes were not responsible for insect population development being slower on whole oats than on cracked oats. Although we were unable to identify the factors that determined relative susceptibility in this study, the results will be useful for selecting commercial oat cultivars for planting that will be less susceptible to insect pests in storage and suggest that the economics of
\end{abstract}

\footnotetext{
*Corresponding author. Tel.: + 1-785-776-2796; fax: + 1-785-537-5584.

E-mail address: throne@gmprc.ksu.edu (J.E. Throne).
} 
cleaning oats before storage to reduce insect population growth should be investigated. (C) 2002 Elsevier Science Ltd. All rights reserved.

Keywords: Avena sativa; C. pusillus; Host plant resistance; Oats; O. surinamensis; Stored products; Trichomes

\section{Introduction}

About 2-3 million tonnes of oats (Avena sativa L.) are harvested each year in the United States, and almost that same amount of oats are stored over the winter (USDA, NASS, 2000). Stored oats are susceptible to infestation by a number of insect pests (Ingemansen et al., 1986). Residual insecticides are used to protect stored oats from damage by insect pests, but alternatives to insecticides are desirable because of the development of resistance by insects to insecticides and regulatory restrictions on use of insecticides (Arthur, 1996). One alternative control technology that has been largely ignored since the widespread use of residual insecticides on stored grain is resistance of grains to insects. Most new grain varieties are selected for agronomic traits, such as yield, but not for resistance to pests in storage (Throne et al., 2000). Little is known about susceptibility of current commercial oat cultivars to storage insect pests. Information on susceptibility of commercial oat cultivars may help to identify resistance traits that already occur in commercial cultivars and that can be incorporated into other cultivars that lack these traits. In addition, this information could be used by producers to select cultivars for planting that are less susceptible to insects in storage or could be used by storage managers to determine safe storage times for different cultivars.

The insects most commonly found in stored oats in the United States are Cryptolestes spp. [flat grain beetle, C. pusillus (Schönherr); and rusty grain beetle, Cryptolestes ferrugineus (Stephens) (Coleoptera: Laemophloeidae)]; the sawtoothed grain beetle, Oryzaephilus surinamensis (L.) (Coleoptera: Silvanidae); the red flour beetle, Tribolium castaneum (Herbst) (Coleoptera: Tenebrionidae); the foreign grain beetle, Ahasverus advena (Waltl) (Coleoptera: Silvanidae); and the hairy fungus beetle, Typhaea stercorea (L.) (Coleoptera: Mycetophagidae) (Horton, 1982; Storey et al., 1983; Ingemansen et al., 1986). Cryptolestes ferrugineus, C. pusillus, O. surinamensis, and $T$. castaneum are considered to be secondary pests of grain; i.e., they are unable to infest intact kernels, and they usually feed and develop outside of grain kernels. However, most harvested grains contain damaged kernels, so grains suitable for development of secondary pests would not be lacking in a bin of grain. Ahasverus advena and T. stercorea are primarily fungus feeders. About $50 \%$ of samples from oats stored for $\leqslant 1$ yr were infested with insects, with average densities of about 30/kg (Ingemansen et al., 1986). Insect density generally increased as moisture content increased above $11 \%$ (Ingemansen et al., 1986).

Sinha $(1969,1971)$ reported that the oat hull provided resistance to storage insect pests, including primary pests (i.e., those pests that can damage intact kernels and that can feed and develop within grain kernels); Vicar, a hulless oat, was the most susceptible cultivar. Cracked oats were more susceptible than whole oats. The hulless oat was not the most susceptible cultivar when the kernels were cracked.

Our objectives were to determine susceptibility of commercial oat cultivars, both cracked and whole, grown in the United States to two of the most commonly found insect pests of stored oats 
in the United States and to determine whether insect development on these cultivars could be correlated with chemical or physical properties of the oats.

\section{Materials and methods}

\subsection{Oats}

Oats used in the study were grown during 1996 in North Dakota using standard agronomic practices. We used two yellow oats - Milton and Brawn; five white oats - Don, Jerry, NewDak, Otana, and Valley; and a hulless oat - Paul. Oats from each cultivar were split into three samples of about $250 \mathrm{~g}$ each, and insect bioassays and chemical and physical analyses were conducted on each of the three samples. Oats were stored below $0^{\circ} \mathrm{C}$ for 2 weeks to kill any incipient insect infestations.

\subsection{Insect bioassays}

We equilibrated the three samples of each oat cultivar in bulk for 4 weeks at $30^{\circ} \mathrm{C}$ over a saturated sodium chloride solution, which maintains relative humidity at 75\% (Greenspan, 1977), before weighing out samples for the bioassays and chemical and physical analyses. The original 4 week equilibration period ensured that oats were close to or at equilibrium moisture content before weighing out samples for bioassays and analyses.

We used a randomized complete block design for bioassays on each of the two insect species, which were tested separately. There were three blocks (or replications) for each species, and blocks were three plastic boxes $(28 \times 38.5 \times 15 \mathrm{~cm}$ high $)$ containing sodium chloride solutions. Treatments for each species were eight cultivars and two kernel conditions-cracked or whole kernels. Thus, each box contained 16 cages - one cage of whole and one cage of cracked oats of each of the eight cultivars, and there were six boxes - two insect species with three blocks each.

After the initial equilibration period, each replication of each oat cultivar was divided into four $20.0 \pm 0.1 \mathrm{~g}$ samples and one $12.0 \pm 0.1 \mathrm{~g}$ sample. Two of the $20 \mathrm{~g}$ samples and the $12 \mathrm{~g}$ sample of each replication of each oat cultivar were transferred to cages $(30$-mm-diameter $\times 81$-mm-high). The other two $20 \mathrm{~g}$ samples of each replication of each oat cultivar were cracked separately for $3 \mathrm{~s}$ in the 50-ml cup of a blender (Waring 5011, New Hartford, CT), and then transferred to cages. All cages had 100-mesh brass screens in the lids. Cages containing $20 \mathrm{~g}$ samples were randomly placed within the six plastic boxes (two species of insects $\times$ three blocks) containing sodium chloride solutions and equilibrated for an additional 2 weeks at $30^{\circ} \mathrm{C}$. The 12 -g samples were placed over a saturated sodium chloride solution in a separate box and equilibrated for an additional 2 weeks at $30^{\circ} \mathrm{C}$. The 12-g samples were used to determine chemical and physical properties of oats (described below).

Insects for the study were from cultures that have been maintained for many years at the USDA-ARS Grain Marketing and Production Research Center at $25^{\circ} \mathrm{C}$ and $60-65 \%$ r.h. Chilled beetles (O. surinamensis were 2-4 weeks old and $C$. pusillus were 2-5 weeks old) were sexed (Halstead, 1963), and 10 females of a species were placed in the appropriate cages to oviposit for $72 \mathrm{~h}$. Sex and identification (Green, 1979; Kingsolver, 1991) of ovipositing females were confirmed 
after the beetles were removed from cages. Emerging adults were removed every $3.5 \mathrm{~d}$ by pouring the contents of a cage into a white enamel pan and removing progeny with forceps, starting $14 \mathrm{~d}$ after the middle of the oviposition period and continuing until no beetles had emerged in each cage for 2 weeks. All studies were conducted at $30^{\circ} \mathrm{C}$ and $75 \%$ r.h., conditions which are nearly optimal for development of these insects (Howe, 1965).

\subsection{Chemical and physical analyses}

The number of kernels in 10-g samples of moisture-equilibrated oats was determined and converted to 1000 kernel weight by dividing into 10,000. Equilibrium moisture content was determined using the air-oven method (AACC, 1981). Percentage groat (groat is the seed inside the hull) was calculated as weight of the groat after dehulling divided by weight of the oat before dehulling (times 100). Percentage broken groats was calculated as weight of broken groats divided by total weight of groats after dehulling (times 100), and is a measure of kernel hardness. Percentages of $\beta$-glucan (McCleary and Glennie-Holmes, 1985), oil (Doehlert and McMullen, 2000), protein (Doehlert and McMullen, 2000), and starch (AACC, 1995) were also determined.

\subsection{Statistical analyses}

We analyzed data for number of progeny produced and duration of development using analysis of variance (PROC GLM, SAS Institute, 1998). Means were compared using Ryan's $Q$ test (Day and Quinn, 1989). We did not include insect species as a factor in the analyses because this was not an objective of the study and because tests for the two species were not conducted entirely simultaneously. There were missing replications because some of the original adults placed in the cages were males and because we were not able to recover all ovipositing $C$. pusillus from the oats (adults crawl inside damaged kernels). We used correlation (PROC CORR, SAS Institute, 1998) to determine relationships between chemical and physical properties of oats and biological parameters of the insects.

We used the Dobie index of susceptibility (Dobie, 1974) to compare long-term population development on each cultivar. The index is calculated as $\left(\log _{e} y\right) / t$, where $y$ is the number of progeny produced and $t$ the duration of development. This index incorporates the number of eggs laid, survivorship to the adult stage, and developmental time. Larger index values indicate greater susceptibility to insects. The index approximates the intrinsic rate of increase (Dobie, 1974). We used the index of susceptibility to simulate population development of each species on cracked and on whole oats at $30^{\circ} \mathrm{C}$ when we started with one gravid female $/ 16 \mathrm{~kg}\left(N_{t}=N_{0} \mathrm{e}^{r t}\right.$, where $N_{0}$ is the initial number of insects, $N_{t}$ is the number of insects at time $t$, and $r$ is the intrinsic rate of increase as approximated by the Dobie index of susceptibility) and to determine when the population would reach the Grain Inspection, Packers, and Stockyards Administration (GIPSA) threshold for insect infestation of 10 live secondary insect pests $/ 0.5 \mathrm{~kg}$ (USDA, GIPSA, 2001). Storage at $30^{\circ} \mathrm{C}$ is comparable to storage during the summer and is a worst case scenario. Insect population development during cooler parts of the year would be slower. 


\subsection{Insect development on whole, steamed oats}

Oats have trichomes on the hull, and we conducted a second study to determine whether whole oats that have been steamed to inactivate hydrolytic enzymes (Doehlert et al., 1997) in the trichomes are more susceptible to insects. Methods used for insect bioassays were almost identical to those used in the first part of the study, except we used $25.0 \pm 0.1 \mathrm{~g}$ of oats in each cage, and cracked oats were not used. Oats were steamed by suspending samples over boiling water in a vegetable steamer for $20 \mathrm{~min}$ (Doehlert et al., 1997).

\section{Results}

\subsection{Insect development on cracked and whole oats}

Duration of development was shorter and number of progeny produced was greater on cracked than on whole oats; however, interaction between kernel condition (whole vs. cracked oats) and cultivar was often significant and variances often were not homogeneous and could not be homogenized by transformation because of the great disparity in progeny production on whole and cracked oats (results of these analyses not shown). Therefore, we analyzed data for cracked and whole oats separately.

The number of progeny produced by $C$. pusillus did not differ with cultivar on cracked oats $(F=0.91 ; \mathrm{df}=7,13 ; P=0.53)$ (Table 1$)$. The number of $C$. pusillus progeny produced was greater on whole Brawn and Paul than on Don or Otana $(F=7.51$; df $=7,10 ; P<0.01)$. Whole Otana was immune to $C$. pusillus. The number of $O$. surinamensis progeny produced was less on cracked Paul than on all other cultivars except Jerry $(F=4.86$; df $=7,12 ; P<0.01)$. The number of $O$. surinamensis progeny produced was less on whole Otana than on all other cultivars $(F=6.90 ;$ df $=7,12 ; P<0.01)$. Variances for $O$. surinamensis on whole oats were not

Table 1

Number of $F_{1}$ progeny produced by two species of insects reared on eight cultivars of cracked and whole oats when 10 females laid eggs for $3 \mathrm{~d}^{\mathrm{a}}$

\begin{tabular}{|c|c|c|c|c|}
\hline \multirow[b]{2}{*}{ Cultivar } & \multicolumn{2}{|l|}{ C. pusillus } & \multicolumn{2}{|l|}{ O. surinamensis } \\
\hline & Cracked & Whole & Cracked & Whole \\
\hline Brawn & $150.0 \pm 5.77$ & $33.0 \pm 7.99 a(2)$ & $126.0 \pm 3.00 \mathrm{a}(2)$ & $40.0 \pm 12.4 \mathrm{a}(3)$ \\
\hline Don & $139.0 \pm 26.6(3)$ & $6.50 \pm 6.50 \mathrm{~b}(2)$ & $120.0 \pm 1.00 \mathrm{a}(2)$ & $13.3 \pm 1.45 \mathrm{a}(3)$ \\
\hline Jerry & $182.3 \pm 11.0$ & $12.5 \pm 3.50 \mathrm{ab}(2)$ & $105.7 \pm 5.48 \mathrm{ab}(3)$ & $29.5 \pm 6.50 \mathrm{a}(2)$ \\
\hline Milton & $145.7 \pm 20.6$ & $16.5 \pm 5.50 \mathrm{ab}(2)$ & $138.3 \pm 9.35 \mathrm{a}(3)$ & $28.3 \pm 3.93 \mathrm{a}(3)$ \\
\hline NewDak & $142.0 \pm 16.9$ & $12.0 \pm 2.00 \mathrm{ab}(2)$ & $142.0 \pm 19.2 \mathrm{a}(3)$ & $24.5 \pm 0.50 \mathrm{a}$ \\
\hline Otana & $155.0 \pm 9.97(2)$ & $0.00 \pm 0.00 \mathrm{~b}(2)$ & $139.0 \pm 14.0 \mathrm{a}(2)$ & $1.50 \pm 1.50 \mathrm{~b}(2)$ \\
\hline Paul & $141.5 \pm 2.50$ & $30.7 \pm 0.33 a$ & $66.5 \pm 11.5 b(2)$ & $21.3 \pm 2.67 \mathrm{a}(3)$ \\
\hline Valley & $128.0 \pm 14.0$ & $13.3 \pm 3.48 \mathrm{ab}(3)$ & $146.7 \pm 7.91 \mathrm{a}(3)$ & $26.5 \pm 1.50 \mathrm{a}(2)$ \\
\hline
\end{tabular}

${ }^{\text {a }}$ Different letters after means ( \pm SE, $n$ in parentheses) within a column indicate significant differences among cultivars using Ryan's $Q$ test (Day and Quinn, 1989). 
Table 2

Duration of immature development (d) of two species of insects reared on eight cultivars of cracked and whole oats ${ }^{\mathrm{a}}$

\begin{tabular}{|c|c|c|c|c|}
\hline \multirow[b]{2}{*}{ Cultivar } & \multicolumn{2}{|l|}{ C. pusillus } & \multicolumn{2}{|l|}{ O. surinamensis } \\
\hline & Cracked & Whole & Cracked & Whole \\
\hline Brawn & $28.7 \pm 0.14 b(3)$ & $41.2 \pm 0.89 \mathrm{ab}(2)$ & $23.8 \pm 0.21$ & $27.1 \pm 0.09 \mathrm{bc}(3)$ \\
\hline Don & $29.5 \pm 0.12 \mathrm{ab}(3)$ & $42.7 \pm-\mathrm{a}(1)$ & $23.3 \pm 0.20$ & $30.0 \pm 1.12 b(3)$ \\
\hline Jerry & $29.3 \pm 0.47 \mathrm{ab}(3)$ & $40.4 \pm 0.55 \mathrm{ab}(3)$ & $23.7 \pm 0.51$ & $30.3 \pm 0.46 b(3)$ \\
\hline Milton & $30.1 \pm 0.09 \mathrm{ab}(3)$ & $42.1 \pm 0.70 \mathrm{ab}(2)$ & $23.4 \pm 0.09$ & $28.9 \pm 0.74 b(3)$ \\
\hline NewDak & $29.1 \pm 0.16 \mathrm{ab}(3)$ & $41.4 \pm 0.71 \mathrm{ab}(2)$ & $23.7 \pm 0.20$ & $28.3 \pm 0.67 b$ \\
\hline Otana & $29.9 \pm 0.34 \mathrm{ab}(3)$ & $- \pm-(0)$ & $23.2 \pm 0.22$ & $33.3 \pm 3.75 \mathrm{a}(2)$ \\
\hline Paul & $30.1 \pm 0.41 \mathrm{ab}(3)$ & $39.1 \pm 0.20 b(3)$ & $24.3 \pm 0.55$ & $23.9 \pm 0.43 \mathrm{c}(3)$ \\
\hline Valley & $30.6 \pm 0.49 a$ & $41.1 \pm 0.27 \mathrm{ab}(3)$ & $23.3 \pm 0.42$ & $27.3 \pm 1.05 \mathrm{bc}(3)$ \\
\hline
\end{tabular}

${ }^{a}$ Different letters after means $( \pm \mathrm{SE}, n$ in parentheses) within a column indicate significant differences among cultivars using Ryan's $Q$ test (Day and Quinn, 1989).

homogeneous, so data were square-root transformed before analysis; untransformed means and standard errors are reported to simplify interpretation.

The duration of development of $C$. pusillus was longer on cracked Valley than on Brawn $(F=3.61 ; \mathrm{df}=7,16 ; P=0.02)$ (Table 2). The duration of development of $C$. pusillus was longer on whole Don than on Paul $(F=4.77$; df $=6,9 ; P=0.02)$. The duration of development of $O$. surinamensis on cracked oats did not differ with cultivar $(F=0.91 ; \mathrm{df}=7,16 ; P=0.52)$. The duration of development of $O$. surinamensis was longer on whole Otana than on other cultivars and shorter on Paul than on most of the other cultivars $(F=8.21$; df $=7,15 ; P<0.01)$.

The Dobie index did not vary with cultivar for $C$. pusillus (cracked oats: $F=0.92$; df $=7,13$; $P=0.52$; whole oats: $F=3.25$; df $=6,8 ; P=0.06$ ). However, whole Otana was not included in the analysis for $C$. pusillus because no progeny were produced on that cultivar, and, thus, the Dobie index could not be calculated. Whole Otana is immune to $C$. pusillus. The Dobie index of susceptibility was smaller for $O$. surinamensis on cracked Paul $(F=7.38$; $\mathrm{df}=7,12 ; P<0.01)$ and on whole Otana $(F=6.91 ; \mathrm{df}=7,11 ; P<0.01)$ than for other cultivars (Table 3$)$. The Dobie index for $O$. surinamensis on whole Otana is overestimated because no progeny were produced in one replication and the Dobie index is undefined when no progeny are produced $\left(\log _{\mathrm{e}}(0)\right.$ is undefined). Thus, the Dobie index was calculated only for the replication in which progeny were produced.

Using the Dobie index of susceptibility to predict population growth, C. pusillus populations on cracked oats would reach the GIPSA threshold between 80 and $110 \mathrm{~d}$ of storage at $30^{\circ} \mathrm{C}$. O. surinamensis populations on cracked oats would reach the GIPSA threshold between 75 and $100 \mathrm{~d}$, except on Paul, where the threshold would not be reached until after $150 \mathrm{~d}$. Any of the oat cultivars could be stored whole for at least a year at $30^{\circ} \mathrm{C}$ without reaching the GIPSA threshold for either species. C. pusillus populations would decrease over time (Dobie index of susceptibility was negative or undefined) on whole Don, Jerry, Milton, NewDak, Otana, and Valley; and they would reach the threshold after 3514 and $9137 \mathrm{~d}$ on Brawn and Paul, respectively. O. surinamensis populations would decrease over time on whole Don, Jerry, Milton, NewDak, Otana, Paul, and Valley; and they would reach the threshold after $823 \mathrm{~d}$ on Brawn. Again, these storage times are worst case scenarios because population development was predicted at $30^{\circ} \mathrm{C}$. Temperatures in 
Table 3

Dobie index of susceptibility for two species of insects reared on eight cultivars of cracked and whole oats ${ }^{\mathrm{a}}$

\begin{tabular}{|c|c|c|c|c|}
\hline \multirow[b]{2}{*}{ Cultivar } & \multicolumn{2}{|l|}{ C. pusillus } & \multicolumn{2}{|l|}{ O. surinamensis } \\
\hline & Cracked & Whole & Cracked & Whole \\
\hline Brawn & $0.056 \pm 0.0013$ & $0.0015 \pm 0.0060$ & $0.060 \pm 0.0008 \mathrm{a}$ & $0.0062 \pm 0.013 \mathrm{a}$ \\
\hline Don & $0.050 \pm 0.0075$ & $-0.020 \pm-(1)^{\mathrm{b}}$ & $0.059 \pm 0.0006 \mathrm{a}(2)$ & $-0.027 \pm 0.0026 \mathrm{a}$ \\
\hline Jerry & $0.062 \pm 0.0030$ & $-0.023 \pm 0.0075$ & $0.053 \pm 0.0016 \mathrm{a}$ & $-0.0012 \pm 0.0073 \mathrm{a}$ \\
\hline Milton & $0.052 \pm 0.0049$ & $-0.015 \pm 0.0080$ & $0.065 \pm 0.0026 a$ & $-0.0028 \pm 0.0046 \mathrm{a}(3)$ \\
\hline NewDak & $0.053 \pm 0.0040$ & $-0.022 \pm 0.0037$ & $0.065 \pm 0.0058 \mathrm{a}$ & $-0.0072 \pm 0.0010 \mathrm{a}$ \\
\hline Otana & $0.054 \pm 0.0021(2)$ & $- \pm-(0)^{\mathrm{c}}$ & $0.066 \pm 0.0053 \mathrm{a}(2)$ & $-0.078 \pm-\mathrm{b}(1)^{\mathrm{b}}$ \\
\hline Paul & $0.052 \pm 0.0012(2)$ & $0.00056 \pm 0.0003$ & $0.032 \pm 0.0083 b(2)$ & $-0.015 \pm 0.0056 a$ \\
\hline Valley & $0.047 \pm 0.0044$ (2) & $-0.022 \pm 0.0074$ & $0.068 \pm 0.0022 \mathrm{a}$ & $-0.0045 \pm 0.0022 \mathrm{a}(2)$ \\
\hline
\end{tabular}

${ }^{a}$ Different letters after means $( \pm$ SE, $n$ in parentheses) within a column indicate significant differences among cultivars using Ryan's $Q$ test (Day and Quinn, 1989).

${ }^{\mathrm{b}}$ No progeny produced in one replication, so Dobie index could not be calculated for that replication. Thus, estimate of Dobie index is overestimated because it is calculated using data only for the replication in which progeny were produced.

${ }^{c}$ No progeny produced in either of the two replications, so Dobie index could not be calculated. This indicates that whole Otana is immune to C. pusillus infestation.

Table 4

Physical parameters of oat cultivars ${ }^{\mathrm{a}}$

\begin{tabular}{lllll}
\hline Cultivar & Thousand kernel weight $(\mathrm{g})$ & \% Groat & \% Broken groats & $\begin{array}{l}\text { \% Moisture content } \\
\text { (wet weight) }\end{array}$ \\
\hline Brawn & $39.7 \pm 1.2 \mathrm{a}$ & $75.6 \pm 0.6 \mathrm{bc}$ & $2.8 \pm 0.24 \mathrm{a}$ & $13.8 \pm 0.32 \mathrm{a}$ \\
Don & $30.8 \pm 0.1 \mathrm{c}$ & $73.0 \pm 0.8 \mathrm{~d}$ & $0.5 \pm 0.10 \mathrm{c}$ & $13.1 \pm 0.06 \mathrm{~b}$ \\
Jerry & $35.3 \pm 0.4 \mathrm{~b}$ & $77.1 \pm 0.2 \mathrm{~b}$ & $2.2 \pm 0.18 \mathrm{ab}$ & $14.1 \pm 0.08 \mathrm{a}$ \\
Milton & $30.1 \pm 0.6 \mathrm{c}$ & $73.1 \pm 0.3 \mathrm{~d}$ & $2.1 \pm 0.12 \mathrm{ab}$ & $13.7 \pm 0.08 \mathrm{a}$ \\
NewDak & $31.0 \pm 0.6 \mathrm{c}$ & $73.5 \pm 0.1 \mathrm{~d}$ & $3.0 \pm 0.44 \mathrm{a}$ & $13.9 \pm 0.10 \mathrm{a}$ \\
Otana & $30.5 \pm 0.8 \mathrm{c}$ & $73.2 \pm 0.2 \mathrm{~d}$ & $0.3 \pm 0.01 \mathrm{c}$ & $14.1 \pm 0.06 \mathrm{a}$ \\
Paul & $24.4 \pm 0.2 \mathrm{~d}$ & $95.6 \pm 0.2 \mathrm{a}$ & $2.5 \pm 0.16 \mathrm{ab}$ & $13.9 \pm 0.03 \mathrm{a}$ \\
Valley & $31.9 \pm 0.7 \mathrm{c}$ & $75.3 \pm 0.2 \mathrm{c}$ & $1.7 \pm 0.30 \mathrm{~b}$ & $14.1 \pm 0.06 \mathrm{a}$ \\
\hline
\end{tabular}

${ }^{\text {a }}$ Different letters after means $( \pm \mathrm{SE}, n=3)$ within a column indicate significant differences among cultivars using Ryan's $Q$ test (Day and Quinn, 1989).

storage bins should be lower during much of the year, so populations would take even longer to reach the GIPSA threshold at lower temperatures.

Chemical and physical properties of the oat kernels differed with cultivar (Tables 4 and 5), except for percentage starch $(F=0.7$; df $=7,16 ; P=0.67)$. Kernels were smallest in Paul and largest in Brawn and Jerry $(F=42.9$; $\mathrm{df}=7,16 ; P<0.01)$. Percentage groat was highest in the hulless cultivar Paul $(F=352$; df $=7,16 ; P<0.01)$. Percentage broken groats after dehulling was lowest in Don and Otana, indicating that they were harder than other cultivars $(F=19.2$; df $=7$, 
Table 5

Chemical parameters of oat cultivars ${ }^{\mathrm{a}}$

\begin{tabular}{lllll}
\hline Cultivar & $\%$ Oil & \% Protein & \% Starch & \% $\beta$-glucan \\
\hline Brawn & $5.5 \pm 0.06 \mathrm{f}$ & $18.8 \pm 0.08 \mathrm{bc}$ & $60.3 \pm 2.0$ & $4.6 \pm 0.06 \mathrm{abc}$ \\
Don & $8.4 \pm 0.05 \mathrm{a}$ & $16.7 \pm 0.19 \mathrm{e}$ & $58.8 \pm 0.3$ & $5.2 \pm 0.40 \mathrm{a}$ \\
Jerry & $5.0 \pm 0.01 \mathrm{~g}$ & $19.9 \pm 0.08 \mathrm{a}$ & $61.1 \pm 1.0$ & $4.3 \pm 0.11 \mathrm{c}$ \\
Milton & $6.7 \pm 0.03 \mathrm{c}$ & $19.1 \pm 0.15 \mathrm{~b}$ & $59.1 \pm 0.8$ & $5.2 \pm 0.06 \mathrm{ab}$ \\
NewDak & $5.8 \pm 0.01 \mathrm{e}$ & $17.9 \pm 0.11 \mathrm{~d}$ & $61.0 \pm 1.2$ & $4.5 \pm 0.06 \mathrm{bc}$ \\
Otana & $5.4 \pm 0.02 \mathrm{f}$ & $17.6 \pm 0.10 \mathrm{~d}$ & $60.4 \pm 0.6$ & $5.3 \pm 0.05 \mathrm{a}$ \\
Paul & $7.6 \pm 0.05 \mathrm{~b}$ & $18.4 \pm 0.06 \mathrm{c}$ & $58.3 \pm 1.4$ & $5.2 \pm 0.03 \mathrm{a}$ \\
Valley & $6.1 \pm 0.03 \mathrm{~d}$ & $18.6 \pm 0.06 \mathrm{c}$ & $60.2 \pm 1.7$ & $4.9 \pm 0.03 \mathrm{abc}$ \\
\hline
\end{tabular}

${ }^{a}$ Different letters after means $( \pm \mathrm{SE}, n=3)$ within a column indicate significant differences among cultivars using Ryan's $Q$ test (Day and Quinn, 1989). All percentages were calculated on a dry weight basis.

16; $P<0.01)$. Equilibrium moisture content was lowest in Don $(F=6.9$; df $=7,16 ; P<0.01)$. Percentage oil was highest in Don and lowest in Jerry $(F=1073 ; \mathrm{df}=7,16 ; P<0.01)$. Percentage protein was highest in Jerry and lowest in Don $(F=78.3 ; \mathrm{df}=7,16 ; P<0.01)$. Percentage $\beta$-glucan was higher in Otana, Don, and Paul than in Jerry $(F=6.1 ; \mathrm{df}=7,16 ; P<0.01)$.

The number of progeny produced was positively correlated [using a sequential Bonferroni test based on an experiment-wide error rate of 0.05 within a species and kernel condition (Rice, 1989)] with percentage broken groats for $C$. pusillus developing on whole oats $(r=0.73, n=18)$ and negatively correlated with percentage groat for $O$. surinamensis developing on cracked oats $(r=-0.75, n=20)$. Duration of development on whole oats was negatively correlated with percentage groat for both species $(r=-0.83$ for $C$. pusillus and -0.68 for $O$. surinamensis; $n=16$ and 23, respectively). The Dobie index of susceptibility for $O$. surinamensis on cracked oats was negatively correlated with percentage groat $(r=-0.83, n=20)$. Other correlations were not significant.

The hulless cultivar Paul, which has a high percentage groat, appeared to have great influence on all of the significant correlations which included percentage groat as a factor. When data for Paul were excluded from those correlation analyses, the only correlation that included percentage groat as a factor that was still significant was with duration of development for C. pusillus developing on whole oats $(r=-0.75$, df $=13)$.

\subsection{Insect development on whole, steamed oats}

Steaming did not increase susceptibility of whole oats to insects. Although the results of the studies using steamed and unsteamed whole oats are not statistically comparable because they were conducted at different times, the mean number of progeny produced on steamed oats was always lower than on unsteamed whole oats for both species and all cultivars, except that whole Otana was immune to $C$. pusillus in both studies (compare data in Table 6 with those in Tables 1 and 2). Thus, there was no indication that inactivation of hydrolytic enzymes in the trichomes increased susceptibility of whole oats to insects. 
Table 6

Number of progeny produced by and duration of immature development of two species of insects reared on eight cultivars of whole oats that were steamed to inactivate hydrolytic enzymes in the trichomes ${ }^{\mathrm{a}}$

\begin{tabular}{llllc}
\hline \multirow{2}{*}{ Cultivar } & \multicolumn{2}{l}{ Number of progeny produced } & \multicolumn{2}{l}{ Duration of development (d) } \\
\cline { 2 - 3 } & C. pusillus & O. surinamensis & C. pusillus & O. surinamensis \\
\hline Brawn & $0.33 \pm 0.33(3)$ & $1.67 \pm 1.20(3)$ & $53.5 \pm-(1)$ & $27.4 \pm 1.9(2)$ \\
Don & $1.67 \pm 0.67(3)$ & $5.33 \pm 2.33(3)$ & $47.4 \pm 2.1(3)$ & $29.4 \pm 1.2(3)$ \\
Jerry & $1.00 \pm 0.58(3)$ & $0.33 \pm 0.33(3)$ & $46.8 \pm 0.3(2)$ & $25.5 \pm-(1)$ \\
Milton & $0.00 \pm 0.00(3)$ & $2.00 \pm 2.00(2)$ & $- \pm-(0)$ & $26.5 \pm-(1)$ \\
NewDak & $2.00 \pm 1.15(3)$ & $2.67 \pm 1.76(3)$ & $52.5 \pm 4.0(2)$ & $28.9 \pm 1.4(2)$ \\
Otana & $0.00 \pm 0.00(3)$ & $0.00 \pm 0.00(3)$ & $- \pm \pm(0)$ & $- \pm \pm(0)$ \\
Paul & $10.3 \pm 1.20(3)$ & $18.0 \pm 5.03(3)$ & $57.6 \pm 1.9(3)$ & $26.0 \pm 0.5(3)$ \\
Valley & $2.00 \pm 0.58(3)$ & $7.00 \pm 5.00(3)$ & $46.4 \pm 0.8(3)$ & $29.3 \pm 1.7(3)$ \\
\hline
\end{tabular}

${ }^{\mathrm{a}}$ Mean $\pm \mathrm{SE}, n$ in parentheses.

\section{Discussion}

All of the oat cultivars were relatively resistant to these two species of insects when whole and, based on our simulations, could be stored safe from significant infestation by these two species at $30^{\circ} \mathrm{C}$ for at least a year if there were no broken kernels. Insect populations would decline on Don, Jerry, Milton, NewDak, Otana, and Valley. Stored grain usually contains many broken kernels, so there would be no shortage of broken kernels in a bin of grain. However, we did not clean our oat samples before we started the experiment, so there may have been some broken kernels in the samples, and our samples should be representative of oats stored commercially. The cultivars tested did not differ in their susceptibility to $C$. pusillus when cracked, but $O$. surinamensis population development would be slower on the hulless cultivar Paul than on the other cultivars when cracked. Sinha $(1969,1971)$ also reported that whole oats were less susceptible to insect pests than cracked oats.

In general, we were unable to correlate insect development on oats with chemical and physical properties of the oats. However, whole Otana was almost immune to insects and also had the hardest kernels (lowest \% broken groats after dehulling). Three $O$. surinamensis progeny developed in one replication on whole Otana, and these progeny may have developed on damaged kernels because we did not remove damaged kernels from our samples of oats. No progeny of either species developed in other replications, so undamaged Otana kernels may be immune to these two species. Resistance was associated with higher percentage groat, but this relationship was based on the influence of the hulless cultivar Paul, which had a much higher percentage groat $(95 \%)$ than other cultivars (about $75 \%$ ). There may be other chemical or physical properties of oats that we did not measure that might be correlated with resistance to these insects.

Oats have trichomes on the pericarp which contain hydrolytic enzymes. Leaf trichomes have been associated with resistance to insects in some field crops (e.g., Gillman et al., 1999; Leite et al., 1999). Steaming inactivates these hydrolytic enzymes (Zhang et al., 1997). However, the oat cultivars that we tested were not more susceptible to insects after steaming. This might imply that these hydrolytic enzymes are not involved in resistance to insects in these oat cultivars or that 
there is an additional mechanism of resistance that protects the kernels from insects even when the hydrolytic enzymes are inactivated.

There were few differences in susceptibility to these insects among these oat cultivars. Other crops in the grass subfamily Pooideae also have little variation in susceptibility to insects. For example, Baker et al. (1991) investigated rice weevil, Sitophilus oryzae (L.) (Coleoptera: Curculionidae), development on 30 US eastern soft wheat (Triticum aestivum L.) cultivars and found that mean development time varied by only $2.5 \mathrm{~d}$ and mean number of progeny produced varied by only 30 individuals. Maize (Zea mays L.), which is in the grass subfamily Panicoideae, is very diverse in its susceptibility to insects. For example, median duration of development of the maize weevil, Sitophilus zeamais Motschulsky, varied by $9.4 \mathrm{~d}$, and the number of progeny produced varied by 265 individuals on 28 Mexican land races of maize (Arnason et al., 1994). The Pooideae occur mainly in temperate regions, while the Panicoideae occur mainly in subtropical and tropical regions. Insect pressure in warmer subtropical and tropical regions would be expected to be greater than in cooler temperate regions; thus, plants in the subtropical and tropical regions may have had greater evolutionary impetus to develop resistance to insect pests.

Our results emphasize the importance of maintaining the integrity of the oat kernel to provide resistance to storage insect pests. Population development is slow on whole oats, even when stored at a high temperature. An economic analysis of the costs/benefits of cleaning oats to remove broken kernels before storage would be useful. Our laboratory and simulation results indicate that no other treatment would be required for long-term storage of whole oats when subject to infestation by $C$. pusillus and $O$. surinamensis. The cultivar Paul is less susceptible to O. surinamensis when the kernels are broken, and whole Don, Jerry, Milton, NewDak, Otana, and Valley are relatively resistant to the insect species tested. Further studies to determine the mechanism(s) of resistance in the more resistant cultivars and to incorporate these resistance traits into other commercial cultivars would be useful.

\section{Acknowledgements}

We thank Karen Babcock, Ann Redmon, and Segen Smith for technical assistance, and Paul Fields (Agriculture and Agri-Food Canada, Winnipeg, MB) and Rob Meagher, Jr. (USDA-ARS CMAVE, Gainesville, FL) for comments on an earlier version of the manuscript. Mention of trade names or commercial products in this article is solely for the purpose of providing specific information and does not imply recommendation or endorsement by the US Department of Agriculture.

\section{References}

[AACC] American Association of Cereal Chemists, 1981. Method 44-15A. In: Approved Methods of the American Association of Cereal Chemists. AACC, St. Paul, MN.

[AACC] American Association of Cereal Chemists, 1995. Method 76-11. In: Approved Methods of the American Association of Cereal Chemists. AACC, St. Paul, MN.

Arnason, J.T., Baum, B., Gale, J., Lambert, J.D.H., Bergvinson, D., Philogene, B.J.R., Serratos, J.A., Mihm, J., Jewell, D.C., 1994. Variation in resistance of Mexican landraces of maize to maize weevil Sitophilus zeamais, in relation to taxonomic and biochemical parameters. Euphytica 74, 227-236. 
Arthur, F.H., 1996. Grain protectants: current status and prospects for the future. Journal of Stored Products Research 32, 293-302.

Baker, J.E., Woo, S.M., Throne, J.E., Finney, P.L., 1991. Correlation of $\alpha$-amylase inhibitor content in Eastern soft wheats with development parameters of the rice weevil (Coleoptera: Curculionidae). Environmental Entomology 20, $53-60$.

Day, R.W., Quinn, G.P., 1989. Comparisons of treatments after an analysis of variance in ecology. Ecological Monographs 59, 433-463.

Dobie, P., 1974. The laboratory assessment of the inherent susceptibility of maize varieties to postharvest infestation by Sitophilus zeamais Motsch. (Coleoptera: Curculionidae). Journal of Stored Products Research 10, 183-197.

Doehlert, D.C., McMullen, M.S., 2000. Genotypic and environmental effects on oat milling characteristics and groat hardness. Cereal Chemistry 77, 148-154.

Doehlert, D.C., Zhang, D., Moore, W.R., 1997. Influence of heat pretreatments of oat grain on the viscosity of flour slurries. Journal of the Science of Food and Agriculture 74, 125-131.

Gillman, J.H., Dirr, M.A., Braman, S.K., 1999. Gradients in susceptibility and resistance mechanisms of Buddleia L. taxa to the two-spotted spider mite (Tetranychus urticae Koch). Journal of the American Society for Horticultural Science 124, 114-121.

Green, M., 1979. Cryptolestes klapperichi Lefkovitch in stored products and its identification (Coleoptera: Cucujidae). Journal of Stored Products Research 15, 71-72.

Greenspan, L., 1977. Humidity fixed points of binary saturated aqueous solutions. Journal of Research of the National Bureau of Standards 81A, 89-96.

Halstead, D.G.H., 1963. External sex differences in stored-products Coleoptera. Bulletin of Entomological Research $54,119-134$.

Horton, P.M., 1982. Stored product insects collected from on-farm storage in South Carolina. Journal of the Georgia Entomological Society 17, 485-491.

Howe, R.W., 1965. A summary of estimates of optimal and minimal conditions for population increase of some stored products insects. Journal of Stored Products Research 1, 177-184.

Ingemansen, J.A., Reeves, D.L., Walstrom, R.J., 1986. Factors influencing stored-oat insect populations in South Dakota. Journal of Economic Entomology 79, 518-522.

Kingsolver, J.M., 1991. Adult beetles (Coleoptera). In: Gorham, J.R. (Ed.), Insect and Mite Pests in Food: An Illustrated Key. USDA Agriculture Handbook Vol. 655, pp. 75-94.

Leite, G.L.D., Picanco, M., Guedes, R.N.C., Skowronski, L., 1999. Effect of fertilization levels, age and canopy height of Lycopersicon hirsutum on the resistance to Myzus persicae. Entomologia Experimentalis et Applicata 91, 267-273.

McCleary, B.V., Glennie-Holmes, M., 1985. Enzymatic quantification of $(1 \rightarrow 3),(1 \rightarrow 4)-\beta$-glucan in barley and malt. Journal of the Institute of Brewing 91, 285-295.

Rice, W.R., 1989. Analyzing tables of statistical tests. Evolution 43, 223-225.

SAS Institute, 1998. The SAS System version 7 for Windows. SAS Institute, Cary, NC.

Sinha, R.N., 1969. Reproduction of stored-grain insects on varieties of wheat, oats, and barley. Annals of the Entomological Society of America 62, 1011-1015.

Sinha, R.N., 1971. Multiplication of some stored-product insects on varieties of wheat, oats, and barley. Journal of Economic Entomology 64, 98-102.

Storey, C.L., Sauer, D.B., Walker, D., 1983. Insect populations in wheat, corn, and oats stored on the farm. Journal of Economic Entomology 76, 1323-1330.

Throne, J.E., Baker, J.E., Messina, F.J., Kramer, K.J., Howard, J.A., 2000. Varietal resistance. In: Subramanyam, Bh., Hagstrum, D.W. (Eds.), Alternatives to Pesticides in Stored-Product IPM. Kluwer Academic Publishers, Boston, MA, pp. 165-192.

[USDA, GIPSA] US Department of Agriculture, Grain Inspection, Packers, and Stockyards Administration, 2001. Official United States standards for grain. http://www.usda.gov/gipsa/reference-library/standard/stds.htm.

[USDA, NASS] US Department of Agriculture, National Agricultural Statistics Service, 2000. Published estimates database. http://www.nass.usda.gov:81/ipedb/.

Zhang, D., Doehlert, D.C., Moore, W.R., 1997. Factors affecting viscosity of slurries of oat groat flours. Cereal Chemistry 74, 722-726. 